\title{
Glottic Cancer pT2 TNM Finding v8
}

National Cancer Institute

\section{Source}

National Cancer Institute. Glottic Cancer pT2 TNM Finding v8. NCI Thesaurus. Code C133114.

Glottic cancer with tumor extending to supraglottis and/or subglottis, and/or with impaired vocal cord mobility. (from AJCC 8th Ed.) 